\title{
Pengaruh Harga dan Promosi Terhadap Keputusan Pelanggan Jasa Pada Hotel Calista Lahat
}

\author{
Tri Rusilawati Kasisariah \\ Sekolah Tinggi Ilmu Ekonomi Serelo Lahat, trirusilawati5@gmail.com
}

\begin{abstract}
ABSTRAK
Penelitian ini bertujuan untuk menguji dan menganalisis pengaruh harga dan promosi terhadap keputusan pelanggan jasa Hotel Calista Lahat. Pengumpulan data dilakukan melalui penyebaran koesioner dan dilaksanakan pada 80 konsumen yang datang ke Hotel Calista Lahat. Analisis data pada penelitian ini menggunakan Analisis Regresi Berganda. Teknik pengambilan sampel yang dipakai adalah metode sensus dan tehnik pengujian data yang digunakan dalam penelitian ini adalah uji t guna membuktikan hipotesis penelitian. Hasil analisis menunjukkan bahwa harga dan promosi berpengaruh positif terhadap keputusan pelanggan jasa pada Hotel Calista Lahat.
\end{abstract}

Kata Kunci: Harga, Promosi dan Pelanggan Jasa

\section{ABSTRACT}

This study aims to examine and analyze the effect of price and promotion on customer decisions for Calista Lahat Hotel services. Data collection was carried out by distributing questionnaires and carried out on 80 consumers who came to Hotel Calista Lahat. Data analysis in this study used Multiple Regression Analysis. The sampling technique used was the census method and the data testing technique used in this study was the $t$ test to prove the research hypothesis. The results of the analysis show that price and promotion have a positive effect on service customer decisions at Hotel Calista Lahat.

Keywords: Prices, Promotions, and Customer Services

\section{A. PENDAHULUAN}

Keputusan pelanggan jasa merupakan salah satu komponen utama dari prilaku konsumen yang mengarah kepada pembelian produk atau jasa. Menurut Setiadi dikutip oleh Etta Mamang Sangadji dan Sopiah, menyatakan bahwa keputusan pembelian konsumen ialah proses penginetgrasian yang mengkombinasikan pengetahuan untuk mengevaluasi dua prilaku alternatif atau lebih, dan memilih salah satu di antaranya. Hasil dari proses pengintegrasian ini ialah suatu pilihan yang disajikan secara kongnitif sebagai keinginan prilaku. Konsumen bebas dalam memilihproduk apa yang di inginkan sesuai kebutuhannya, memutuskan apa yang dibelinya,banyaknya pembelian,kapan membeli,tempat pembelian,cara pembayaran dan mengapa ia harus membeli suatu produk tersebut.

Sebelum memutuskan untuk menggunakan jasa, biasanya konsumen melalui beberapa tahapan terlebih dahulu misalnya pengenalan masalah, pencapaian informasi,evaluasi tehadap alternatif penggunaan, keputusan menggunakan. Masalah timbul dari dalam diri konsumen yang berupa kebutuhan yang digerakkan oleh pangsangan dari dalam diri konsumen itu sendiri, setelah timbul masalah yang mendorong konsumen untuk memenuhi kebutuhannya kemudian konsumen akan mencari informasi tentang objek yang bisa memuaskan keinginan dari informasi yang diperoleh konsumen tersebut digunakan untuk memperoleh gambar yang lebih 
jelas mengenai suatu produk, selanjutnya setelah tahap tersebut konsumen akan menentukan harga yang ditawarkan untuk melakukan penggunaan jasa tersebut.

Kepututusan penggunaan jasa yang dilakukan oleh konsumen tidak terlepas dari faktor-faktor yang mempengaruhi konsumen untuk melakukan penggunaan jasa, dari faktor-faktor inilah konsuen akan melakukan penilaian terhadap berbagai alternatif pilihan dan memilah salah satu atau lebih alternatif yang diperlukan berdasarkan pertimbangan, salah satu faktor yang dapat mempengaruhi konsumen dalam mengambil keputisan penggunaan terhadap jasa adalah harga dan promosi.

Kegiatan-kegiatan tersebut beroperasi dalam suatu lingkungan yang dibatasi oleh sumber-sumber dari perusahaan itu sendiri, peraturan-peraturan maupun konsekuensi sosial dari perusahaan. Pada umumnya dalam pemasaran perusahaan berusaha menghasilkan laba dari penjualan barang dan jasa yang dilakukan untuk mengembangkan, mempromosikan, mendistribusikan program-program dan jasa yang disponsori oleh organisasi non laba.

Inti dari latar belakang ini adalah pengaruh harga dan promosi dimana yang terdiri dari dua variabel yaitu harga dan promosi. Kedua unsur tersebut saling berkaitan satu sama lain untuk dapat menghasilkan kombinasi harga dan promosi dengan baik sesuai dengan tujuan perusahaan. dengan demikian perusahaan harus menerapkan keputusan yang tepat, guna mendapatkan peluang dan kesempatan dalam meraih posisi yang lebih baik.

Banyaknya bentuk layanan jasa Hotel di Lahat,menuntut Hotel Calista Lahat untuk terus meningkatkan kualitasnya, agar tidak mudah tersalip oleh saingan Hotelhotel lain yang ada di Lahat, maka sebagai sebuah jasa yang intangible (tidak terlihat) harus memperhatikan pelayanan yang optimal karena itu merupakan salah satu kekuatan dari sebuah jasa.

Selain Harga, faktor penting yang mempengaruhi keputusan pelanggan jasa adalah promosi,promosi yang memiliki kualitas yang baik dan unik, dapat mendorong perusahaan untuk mempertahankan usahanya dan mampu bersaing dengan pesaing lainnya.

\section{B. KAJIAN TEORI \\ 1. Harga}

Penetapan harga merupakan keputusan kritis yang menunjang keberhasilan operasi organisasi profit maupun non profit. Harga merupakan satu-satunya bauran pemasaran yang memberikan pendapatan bagi organisasi. Namun, keputusan mengenai harga (terutama dalam konteks pemasaran jasa) tidak mudah dilakukan. Di satu sisi, harga yang terlalu mahal bisa meningkatkan laba jangka pendek, tetapi disisi lain akan sulit dijangkau konsumen dan sukar bersaing dengan kompetitor. Sedangkan bila harga terlalu murah, pangsa pasar bisa melonjak, namun margin konstribusi dan laba bersih yang diperoleh akan berkurang. Selain itu, sebagian konsumen bisa saja mempresepsikan kualitas yang tidak memuaskan (Thamrin, 2016:65).

Menurut Avanti (2013:32) Harga adalah salah satu elemen bauran pemasaran yang menghasilkan pendapatan, elemen lain menghasilkan biaya. Mungkin harga adalah elemen termudah dalam program pemasaran untuk disesuaikan; fitur produk, saluran, dan bahkan komunikasi membutuhkan lebih banyak waktu. Harga juga 
dapat mengkomunikasikan positioning nilai yang dimaksudkan dari produk atau merek perusahaan ke pasar.

\section{Promosi}

Promosi menurut Ujang (2013:426) promosi merupakan berbagai kegiatan yang dilakukan antar perusahaan untuk mengkomunikasikan manfaat dari produknya dan untuk meyakinkan konsumen sasaran agar membelinya. Sementara Nugroho (2012:98) mengungkapkan arti promosi adalah suatu upaya atau kegiatan perusahaan dalam mempengaruhi "konsumen aktual" maupun "konsumen potensial" agar mereka mau melakukan pembelian terhadap produk yang ditawarkan, saat ini atau dimasa yang akan datang. Alat promosi (promotion tools) diklarifikasikan sebagai berikut : 1. Periklanan (advertising). 2. Penjualan perorangan (personal selling). 3. Promosi penjualan (sales promotion). 4. Hubungan masyarakat (public relation) 5. Pemasaran langsung (direct marketing)

\section{Keputusan Pelanggan Jasa}

Abdul (2016:87) keputusan pelanggan jasa adalah tindakan yang langsung terlibat untuk mendapatkan, mengkonsumsi, dan menghabiskan produk dan jasa, termasuk proses keputusan yamg mendahului dan tindakan ini. Pelanggan bisa memilih kapan, dimana dan bagaimana mereka menggunakan produk. Sedangkan dalam proses pembelian dan konsumsi jasa, sebagian besar jasa produksi dan dikonsumsi bersamaan. Konsekuensinya, perusahaan jasa berpeluang besar untuk secara aktif membantu pelanggan memaksimumkan nilai dari pengalaman konsumsinya.

Suryani (2015:36) menyatakan dimensi dari variabel keputusan menginap antara lain : a) Pengenalan Masalah. Indikator Pengenalan masalah terdiri dari Tersedianya Produk untuk Kebutuhan konsumen saat menginap di Hotel dan Kebutuhan terhadap produk sangat tinggi, b) Pencarian Informasi. Indikator dari pencarian informasi antara lain Informasi produk Hotel diperoleh dari Keluarga dan Media Massa, c) Evaluasi Alternatif. Indikatornya adalah Hotel menjadi Prioritas utama sebagai tempat menginap konsumen, d) Keputusan Pembelian. Indikatornya Produk yang ditawarkan pihak Hotel sesuai dengan Kebutuhan serta Saat yang tepat untuk melakukan pembelian produk, e) Evaluasi Perilaku Pasca Pembelian. Indikatornya Konsumen merasa puas terhadap produk Hotel dan Konsumen merekomendasikan Hotel kepada orang lain

\section{Hipotesis}

Menurut Sugiyono (2013:93) Hipotesis merupakan Jawaban sementara terhadap rumusan masalah penelitian biasanya disusun dalam bentuk kalimat pertanyaan.

Adapun Hipotesis yang penulis ambil :

1. Harga dan promosi secara bersama-sama (simultan) berpengaruh signifikan dalam Meningkatkan Keputusan Pelanggan Jasa Pada Hotel Calista Lahat

2. Harga berpengaruh signifikan dalam Meningkatkan Keputusan Pelanggan Jasa Pada Hotel Calista Lahat

3. Promosi berpengaruh signifikan dalam Meningkatkan Keputusan Pelanggan Jasa Pada Hotel Calista Lahat 


\section{METODE PENELITIAN}

Penelitian ini menggunakan rancangan penelitian Asosiatif Kuantitatif menurut Sugiyono (2016:2) penelitian asosiatif adalah penelitian yang bertujuan mengetahui hubungan dan pengaruh dua variabel atau lebih. Dalam penelitian ini akan dibahas mengenai harga dan promosi terhadap keputusan pelanggan jasa pada Hotel Calista Lahat.

Populasi yang diambil dalam penelitian ini adalah seluruh pelanggan yang menginap pada Hotel Calista Lahat yang berjumlah 100 orang, dalam periode dua bulan yaitu bulan Maret - April tahun 2021. Teknik pengambilan sampel yang digunakan dalam penelitian ini adalah Insidental Sampling, yaitu teknik penentuan samel berdasarkan kebetulan, yaitu siapa saja yang secara kebetulan bertemu dengan peneliti dapat digunakan sebagai sampel, bila dipandang orang yang kebetulan ditemui itu cocok sebagai sumber data.

Salah satu cara menentukan besaran sampel adalah yang dirumuskan oleh Slovin (Steph Ellen, eHow Blog, 2010) sebagai berikut taraf keyakinan dalam penelitian ini $95 \%$, yaitu yakin bahwa $95 \%$ hasil penelitian benar, atau taraf signifikansi 0,05 (hanya akan ada $5 \%$ saja kesalahan karena "kebetulan benar" terjadi). $n=N /\left(1+\mathrm{Ne}^{\wedge} 2\right)=100 /(1+100 \times 0,05 \times 0,05)=80$ orang. Jadi Sampel penelitian ini adalah pelanggan yang menginap pada Hotel Calista Lahat yang berjumlah 80 orang.

Sumber data dalam penelitian ini adalah sebagai berikut:

1) Data Primer

Yaitu data yang didapat dari sumber pertama baik dari individu atau perseorangan. Pengumpulan data primer ini dilakukan dengan melakukan survei langsung ke Hotel Calista Lahat sebagai objek penelitian, dengan tujuan untuk memperoleh data akurat

2) Data Skunder

Yaitu data primer yang telah diolah lebih lanjut dan disajikan baik oleh pihak pengumpul data primer atau oleh pihak lain.

Metode pengumpulan data pada penelitian ini menggunakan dua cara, yaitu :

1) Wawancara

Yaitu teknik pengumpulan data dalam metode survei yang menggunakan pertanyaan secara lisan kepada subjek penelitian.

2) Quisioner

Yaitu proses pengambilan data dengan menggunakan/ memberikan bentuk pertanyaan. Pengisian quesioner diukur dengan menggunakan skala likert yang digunakan untuk mengukur sikap, pendapat dan persepsi seseorang atau sekelompok orang tentang fenomena sosial.

\section{Uji Asumsi Klasik \\ 1. Uji Normalitas Data}

Uji normalitas data dilakukan untuk mengetahui normal tidaknya distribusi data (Ghozali, 2013: 98), hipotesis pengujian:

$H_{o} \quad=$ sampel dari populasi berdistribusi normal

$H_{I} \quad=$ sampel dari populasi tidak berdistribusi normal

Mengambil harga yang tersebar diantara harga mutlak selisih tersebut dan harga mutlak tersebut disebut $L_{o}$. Kesimpulan: 
a. Jika $L_{0 \text { hitung }}>L_{\text {tabel }}$ maka $H_{o}$ diterima sebagai dsitribusi sebaran data tidak normal

b. Jika $L_{0 \text { hitung }}<L_{\text {tabel }}$ maka $H_{o}$ diterima sebagai distribusi sebaran data normal

\section{Uji Multikolinearitas}

Pengujian ini dialkukan dengan tujuan untuk menguji apakah pada model regresi ditemukan adanya kolerasi antar variabel bebas. Ini perlu dilakukan karena model regresi yang baik seharusnya tidak terjadi kolerasi antara variabel independen Ghozali (2013: 105). Untuk mendeteksi ada tidaknya multikolinearitas didalam model regresi melalui Variance Inflastion Factor (VIF). Pengujian ini menggunakan bantuan SPSS versi 20.0.

Rumus yang digunakan:

$$
V I F=\frac{1}{1-R i^{2}}
$$

a. Jika $V I F>10$ maka variabel bebas memliki persoalan multikolinearitas dengan variabel bebas lainnya

b. Jika $V I F<10$ maka variabel bebas tidak mempunyai persoalan multikolinearitas

\section{Uji Heteroskedastisitas}

Uji Heteroskedastisitas digunakan untuk menentukan apakah suatu model terbebas dari masalah heteroskedastisitas atau tidak hanya dengan melihat pada Scatter Plot dan dilihat apakah residual memiliki pola tertentu atau tidak. Pengujian ini dilakukan dengan menggunkan program SPSS versi 20.0 Dengan rumus:

$$
|\mathrm{e}|=\mathrm{b} 1+\mathrm{b} 2 \mathrm{X} 2+v
$$

Dimana:

$|\mathrm{e}|=$ Nilai Absolut dari residual yang dihasilkan dari regresi model

$\mathrm{X} 2=$ Variabel penjelas

\section{Kriteria Penguji Hipotesis}

\section{Uji t}

Uji t ini digunakan untuk mengetahui signifikasi ada tidaknya pengaruh variabel bebas terhadap variabel terikat secara parsial atau sendiri-sendiri. Apabila nilai thitung $>$ ttabel atau $\alpha<0,05$, maka $\mathrm{Ho}$ ditolak dan $\mathrm{H}_{\mathrm{i}}$ diterima yang berarti variabel independen berpengaruh secara signifikan terhadap variabel dependen.

\section{Uji f}

Uji F digunakan untuk mengetahui secara bersama-sama pengaruh variabelvariabel bebas terhadap variabel terikat digunakan uji $\mathrm{F}$, dengan asumsi bahwa : jika $\mathrm{P}$ Value $<\alpha$, maka $\mathrm{Ho}$ ditolak, dan $\mathrm{H}_{\mathrm{i}}$ diterima pada tingkat kepercayaan $95 \%$.

\section{Koefisien Korelasi dan Koefisien Determinasi}

Analisis ini digunakan untuk mengetahui seberapa besar sumbangan yang diberikan variabel bebas terhadap variabel terikat yang ditunjukkan dalam persentase. 


\section{HASIL PENELITIAN}

1. Uji Validitas

Uji validitas digunakan untuk menguji sejauh mana ketepatan alat pengukur dapat mengungkapkan konsep gejala/kejadian yang diukur. Item kuesioner dinyatakan valid apabila nilai $r$ hitung $>r$ tabel $(n-3)$. Indikator dikatakan valid dalam penelitian ini, apabila $n=80$ dan $\alpha=0,05$, maka $r$ tabel $=0,220$. dengan ketentuan: Hasil $r$ hitung $>r$ tabel $(0,220)=$ valid.

Hasil $r$ hitung $<r$ tabel $(0,220)=$ tidak valid

Pengujian validitas selengkapnya dapat dilihat pada tabel per varibel berikut:

a) Variabel Harga $\left(X_{1}\right)$

Tabel Hasil Pengujian Validitas

\begin{tabular}{cccc}
\hline Nomor indikator & $r_{\text {hitung }}$ & $r_{\text {tabel }}$ & Keterangan \\
\hline 1 & 0,302 & 0,220 & Valid \\
2 & 0,309 & 0,220 & Valid \\
3 & 0,233 & 0,220 & Valid \\
4 & 0,471 & 0,220 & Valid \\
5 & 0,534 & 0,220 & Valid \\
6 & 0,257 & 0,220 & Valid \\
7 & 0,264 & 0,220 & Valid \\
8 & 0,445 & 0,220 & Valid \\
9 & 0,532 & 0,220 & Valid \\
10 & 0,262 & 0,220 & Valid \\
\hline
\end{tabular}

Sumber: Data primer yang diolah (2021)

Dari hasil uji validitas tabel diatas menunjukan bahwa nilai $r$ hitung $>r$ tabel, dimana semua butir pertanyaan 1 sampai 10 adalah valid. Sehingga dapat disimpulkan bahwa semua item pertanyaan dinyatakan valid dengan alat ukur yang digunakan dalam penelitian ini sesuai untuk mengukur variabel harga

b) Variabel Promosi $\left(X_{2}\right)$

Tabel Uji Validitas

\begin{tabular}{cccc}
\hline Nomor indikator & $r_{\text {hitung }}$ & $r_{\text {tabel }}$ & Keterangan \\
\hline 1 & 0,306 & 0,220 & Valid \\
2 & 0,308 & 0,220 & Valid \\
3 & 0,353 & 0,220 & Valid \\
4 & 0,439 & 0,220 & Valid \\
5 & 0,416 & 0,220 & Valid \\
6 & 0,255 & 0,220 & Valid \\
7 & 0,260 & 0,220 & Valid \\
8 & 0,374 & 0,220 & Valid \\
9 & 0,452 & 0,220 & Valid \\
10 & 0,296 & 0,220 & Valid \\
\hline
\end{tabular}

Sumber: Data primer yang diolah (2021)

Dari hasil uji validitas tabel diatas menunjukan bahwa nilai $r$ hitung $>r$ tabel, dimana semua butir pertanyaan 1 sampai 10 adalah valid. Sehingga dapat disimpulkan bahwa semua item pertanyaan dinyatakan valid dengan alat ukur yang digunakan dalam penelitian ini sesuai untuk mengukur variabel promosi. 


\section{c) Keputusan Pelanggan (Y)}

Tabel Uji Validitas

\begin{tabular}{|c|c|c|c|}
\hline Nomor indikator & $r_{\text {hitung }}$ & $r_{\text {tabel }}$ & Keterangan \\
\hline 1 & 0,249 & 0,220 & Valid \\
\hline 2 & 0,284 & 0,220 & Valid \\
\hline 3 & 0,546 & 0,220 & Valid \\
\hline 4 & 0,266 & 0,220 & Valid \\
\hline 5 & 0,394 & 0,220 & Valid \\
\hline 6 & 0,411 & 0,220 & Valid \\
\hline 7 & 0,262 & 0,220 & Valid \\
\hline 8 & 0,317 & 0,220 & Valid \\
\hline 9 & 0,335 & 0,220 & Valid \\
\hline 10 & 0,379 & 0,220 & Valid \\
\hline
\end{tabular}

Sumber: Data primer yang diolah (2021)

Dari hasil uji validitas tabel diatas menunjukan bahwa nilai $r$ hitung $>r$ tabel, dimana semua butir pertanyaan 1 sampai 10 adalah valid. Sehingga dapat disimpulkan bahwa semua item pertanyaan dinyatakan valid dengan alat ukur yang digunakan dalam penelitian ini sesuai untuk mengukur variabel keputusan pelanggan.

\section{Uji Reliabilitas}

Pada uji reliabilitas dilakukan dengan menggunakan alpha cronbach's. Angka yang didapat melalui metode alpha cronbach's kemudian dibandingkan dengan koefisien $(r)=0,600$. Bila nilai alpha cronbach's lebih besar maka variabel dikatakan reliabel atau terpercaya. Untuk mengetahui selengkapnya hasil penelitian untuk reliabilitas variabel harga $\left(X_{1}\right)$ dan variabel promosi $\left(X_{2}\right)$ terhadap variabel keputusan pelanggan $(\mathrm{Y})$ pada tabel berikut:

Tabel Hasil Uji Reliabilitas

\begin{tabular}{l|l|l|l}
\hline Variabel & Nilai Alpha & Nunnaly & Status \\
\hline Harga & 0,664 & 0,600 & Reliabel \\
Promosi & 0,614 & 0,600 & Reliabel \\
Keputusan Pelanggan & 0,678 & 0,600 & Reliabel \\
\hline
\end{tabular}

Dari tabel tersebut diatas, dapat disimpulkan bahwa nilai alpha cronbach's variabel harga $\left(X_{1}\right)$ dan variabel promosi $\left(X_{2}\right)$ terhadap variabel keputusan pelanggan $(\mathrm{Y})$ yang diperoleh lebih besar dari 0,600 , maka dapat disimpulkan bahwa instrumen untuk ketiga variabel adalah reliabel atau terpercaya.

\section{Uji Normalitas}

Uji normalitas bertujuan untuk menguji apakah dalam model regresi, variabel bebas dan variabel terikat, keduanya terdistribusikan secara normal ataukah tidak. Dengan ketentuan:

a. Jika Responden > 50, maka membacanya pake Kolmogorov-Smirnov

b. Jika Responden $\leq 50$, maka membacanya pake Shapiro-Wilk

Responden pada penelitian ini jumlahnya 80 , jadi tabel yang dilihat ialah Tabel Shapiro -Wilk. Uji normalitas ini dapat dilihat dari tabel berikut: 
Tabel Tests of Normality

\begin{tabular}{|l|r|r|r|r|r|r|}
\hline & \multicolumn{3}{|c|}{ Kolmogorov-Smirnov ${ }^{\mathrm{a}}$} & \multicolumn{3}{c|}{ Shapiro-Wilk } \\
\cline { 2 - 7 } & Statistic & \multicolumn{1}{|c|}{ df } & \multicolumn{1}{c|}{ Sig. } & Statistic & \multicolumn{1}{c|}{ df } & \multicolumn{1}{c|}{ Sig. } \\
\hline Harga & .094 & 80 & .076 & .974 & 80 & .097 \\
Promosi & .111 & 80 & .016 & .977 & 80 & .159 \\
Keputusan Pelanggan & .127 & 80 & .003 & .960 & 80 & .084 \\
\hline
\end{tabular}

a. Lilliefors Significance Correction

Sumber: Data primer yang diolah (2021)

Dari hasil perhitungan SPSS pada penelitian ini, normalitas dipenuhi jika hasil uji tidak signifikan untuk suatu taraf signifikasi $(a)=0.05$. Pada variabel harga $\left(X_{1}\right)$ taraf signifikannya lebih besar $(0,097>0,05)$ dengan demikian, data berasal dari populasi yang berdistribusi normal, variabel promosi $\left(X_{2}\right)$ taraf signifikannya lebih besar $(0,159>0,05)$ dengan demikian, data berasal dari populasi yang berdistribusi normal dan variabel keputusan pelanggan $(Y)$ taraf signifikannya lebih besar $(0,084>$ $0,05)$ dengan demikian, data yang diteliti pada penelitian ini berasal dari populasi yang berdistribusi normal.

\section{Uji Multikolinearitas}

Pengujian multikolinieritas bertujuan untuk mengetahui hubungan yang sempurna antar variabel bebas dalam model regresi. Gejala multikolinieritas dapat dilihat dari nilai tolerance dan nilai Varian Inflation Factor (VIF). Bila nilai VIF lebih kecil dari 10 dan nilai toleransinya di atas 0,1 atau $10 \%$ maka dapat disimpulkan bahwa model regresi tersebut tidak terjadi multikolinieritas. Hal ini dapat dilihat pada tabel hasil SPPS:

Tabel Coefficients ${ }^{a}$

\begin{tabular}{|ll|r|r|}
\hline \multirow{2}{*}{ Model } & \multicolumn{2}{c|}{ Collinearity Statistics } \\
\cline { 2 - 3 } & Tolerance & \multicolumn{1}{c|}{ VIF } \\
\hline \multirow{2}{*}{ (Constant) } & & \\
& Harga & .475 & 2.105 \\
Promosi & .475 & 2.105 \\
\hline
\end{tabular}

a. Dependent Variable: Keputusan Pelanggan

Sumber: Data primer yang diolah (2021)

Dari tabel tersebut menunjukkan bahwa nilai VIF $x_{1}$ (variabel harga) adalah 2,105 , VIF $X_{2}$ (promosi) adalah 2,105. Semuanya lebih kecil dari 10 sehingga tidak ada masalah multikolinearitas.

\section{Uji Heterokedastisitas}

Pengujian bertujuan menguji apakah dalam model regresi terjadi ketidaksamaan variance dari residual satu pengamatan ke pengamatan yang lain. Jika varian dari residual dari satu pengamatan ke pengamatan yang lain tetap, maka disebut homoskedastisitas dan jika varian berbeda, disebut heterokedastisitas. Model regresi yang baik adalah tidak terjadi heterokedastisitas. Untuk mendeteksi ada tidaknya heterokedastisitas dapat digunakan metode grafik Scatterplot yang dihasilkan dari output program SPSS, apabila pada gambar menunjukkan bahwa 
titik-titik menyebar secara acak serta tersebar baik di atas maupun di bawah angka 0 pada sumbu $Y$, maka hal ini dapat disimpulkan tidak terjadi adanya heterokedastisitas pada model regresi.

\section{Gambar Pengujian Heteroskedastisitas}

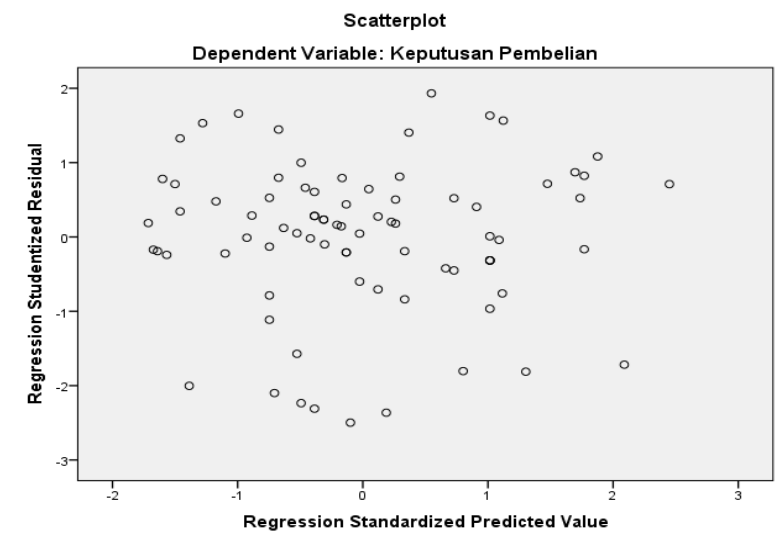

Dari grafik tersebut terlihat titik-titik yang menyebar secara acak, tidak membentuk suatu pola tertentu yang jelas, serta tersebar baik di atas maupun di bawah angka 0 (nol) pada sumbu $\mathrm{Y}$, hal ini berarti tidak terjadi penyimpangan asumsi klasik heterokedastisitas pada model regresi yang dibuat, dengan kata lain menerima hipotesis homoskedastisitas.

\section{Hasil Regresi Linier Berganda}

Analisis regresi linier berganda digunakan untuk mengetahui besarnya pengaruh variabel independen terhadap variabel dependen. Analisis regersi linier berganda pada penelitian ini dapat dilihat pada hasil SPSS dibawah ini:

Tabel Coefficients ${ }^{a}$

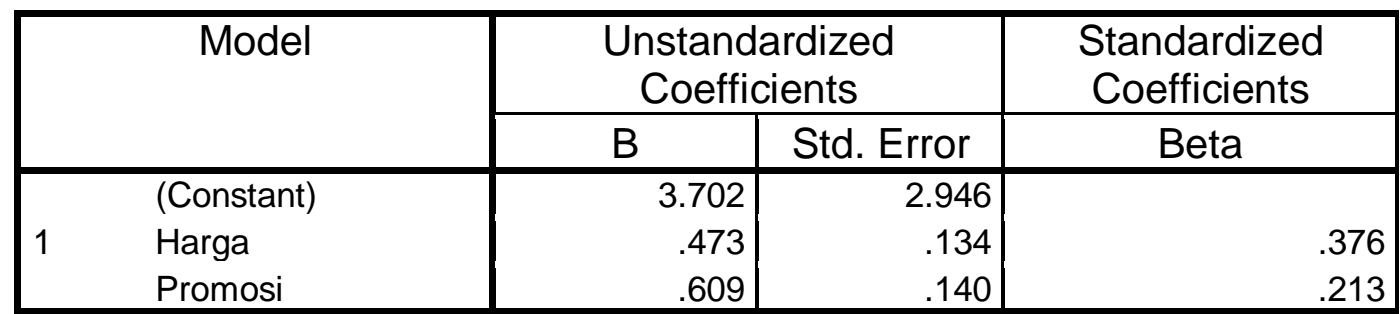

a. Dependent Variable: Keputusan Pelanggan

Sumber: Data primer diolah (2021)

Berdasarkan hasil pengolahan data menggunakan SPSS seperti yang telah disajikan pada tabel diatas, persamaan regresi yang didapat adalah:

$$
Y=3,702+0,473 X 1+0,609 X 2
$$

Persamaan tersebut dapat disimpulkan bahwa bila tanpa adanya variabel harga $\left(X_{1}\right)$, variabel promosi $\left(X_{2}\right)$, maka nilai variabel keputusan pelanggan $(Y)$ sebesar 3,702 .

- Apabila variabel harga $\left(X_{1}\right)$ dinaikan satu satuan maka akan meningkatkan sementara variabel keputusan pelanggan $(\mathrm{Y})$ sebesar 0,473. 
- Apabila variabel promosi $\left(X_{2}\right)$ dinaikan satu satuan maka akan meningkatkan variabel keputusan pelanggan (Y) sebesar 0,609

\section{Uji t}

Uji t dilakukan untuk menguji kebenaran hipotesis dari penelitian ini, yaitu diduga ada pengaruh signifikan. Uji hipotesis ini dilakukan dengan menggunakan nilai $t$ hitung dengn nilai t tabel. Nilai t hitung dapat dilihat pada hasil pengolahan data SPSS tabel berikut:

Tabel Coefficients ${ }^{a}$

\begin{tabular}{|c|c|c|}
\hline Model & $t$ & Sig. \\
\hline $\begin{array}{ll}1 & \text { (Constant) } \\
\text { Harga } \\
\text { Promosi }\end{array}$ & $\begin{array}{l}4.867 \\
2.725 \\
2.543\end{array}$ & $\begin{array}{l}.000 \\
.008 \\
.007\end{array}$ \\
\hline
\end{tabular}

a. Dependent Variable: Keputusan Pelanggan

Sumber: Data primer diolah (2021)

Nilai t tabel dengan tingkat signifikan $5 \%$ dan degrees of freedom (df) dengan $\mathrm{dk}$ pembilang 3 dan $\mathrm{dk}$ penyebut 80 , maka t tabel adalah 2,000. Dengan membandingkan nilai t hitung dan t tabel maka dapat disimpulkan:

a. Variabel harga dengan t hitung $>$ dari t tabel atau 2,725 $>2,000$, maka Ho ditolak dan $\mathrm{Hi}$ diterima, hal ini menunjukan bahwa terdapat pegaruh yang signifikan antara variabel harga dalam Meningkatkan Keputusan Pelanggan Jasa Pada Hotel Calista Lahat

b. Variabel persepsi konsumen dengan t hitung $>$ dari t tabel atau 2,543 $>2,000$, maka $\mathrm{Ho}$ ditolak dan $\mathrm{Hi}$ diterima, hal ini menunjukan bahwa terdapat pegaruh yang signifikan antara variabel promosi dalam Meningkatkan Keputusan Pelanggan Jasa Pada Hotel Calista Lahat.

\section{Uji F}

Uji hipotesis simultan digunakan untuk mengetahui apakah variabel bebas mempunyai pengaruh atau tidak terhadap variabel terikat. Nilai F hitung dapat dilihat dari hasil pengolahan data yang menggunakan SPSS pada tabel berikut:

Tabel ANOVA ${ }^{\mathrm{a}}$

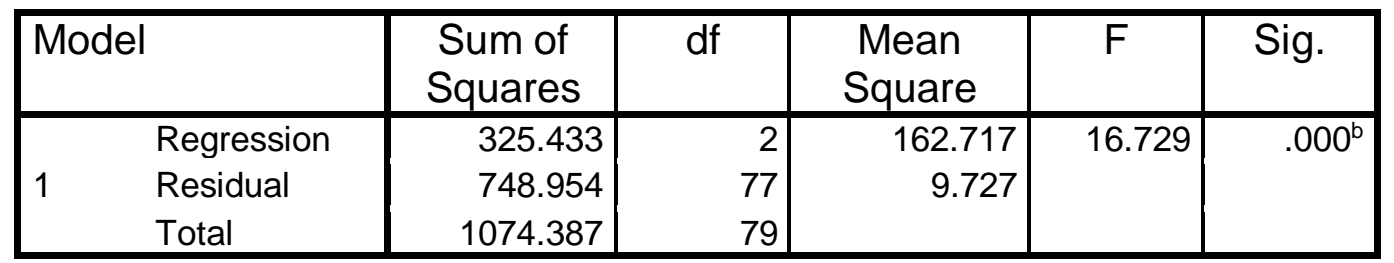

a. Dependent Variable: Keputusan Pelanggan

b. Predictors: (Constant), Promosi, Harga

Sumber: Data diolah (2021)

Uji hipotesis simultan dilakukan dengan membandingkan nilai $F$ hitung dengan nilai $F$ tabel. Nilai $F$ hitung dapat dilihat dari hasil pengolahan data bagian ANOVA. Nilai $\mathrm{F}$ tabel dengan tingkat signifikan $5 \%$ dan degrees of freedom (df) dengan $\mathrm{dk}$ pembilang 3 dan dk penyebut 80 adalah sebesar 8,57. Hasil pengolahan data 
diketahui bahwa nilai $F$ hitung sebesar 16,729. Sehingga nilai $F$ hitung $>F$ tabel. Dari hasi uji hipotesis tersebut maka keputusan yang diambil adalah menolak Ho dan $\mathrm{Hi}$ diterima, artinya secara bersama-sama variabel harga dan variabel promosi secara keseluruhan mempunyai pengaruh yang signifikan dalam meningkatkan keputusan pelanggan jasa pada Hotel Calista Lahat.

\section{Koefisien Determinasi}

Koefisien Determinasi digunakan untuk mengetahui seberapa besar pengaruh variabel bebas terhadap variabel terikat. Nilai uji determinasi dapat dilihat dari tabel hasil olah data dengan menggunakan SPSS pada tabel berikut:

Tabel Model Summaryb

\begin{tabular}{|l|r|r|r|r|}
\hline Model & $\mathrm{R}$ & R Square & \multicolumn{1}{|c|}{$\begin{array}{c}\text { Adjusted R } \\
\text { Square }\end{array}$} & $\begin{array}{c}\text { Std. Error of the } \\
\text { Estimate }\end{array}$ \\
\hline 1 & $.850^{\mathrm{a}}$ & .723 & .125 & 3.11876 \\
\hline
\end{tabular}

a. Predictors: (Constant), Promosi, Harga

b. Dependent Variable: Keputusan Pelanggan

\section{Sumber: Data primer diolah (2021)}

Besarnya nilai koefesien determinasi $\left(r^{2}\right)$ berdasarkan tabel pengolahan data SPPS di atas sebesar 0,723. Artinya pengaruh variabel keputusan pelanggan Jasa Pada Hotel Calista Lahat dapat dijelaskan oleh variabel harga dan variabel promosi dengan kontribusi sebesar 72,3\%, sedangkan sisanya sebesar 27,7 \% dapat dijelaskan oleh variabel lain yang tidak dimasukan dalam model penelitian ini.

\section{E. PEMBAHASAN}

Bagi suatu hotel sebagai perusahaan jasa kualitas layanan merupakan faktor yang penting dan perlu perhatian dari pihak manajemen hotel, karena jika merasa sudah cukup dengan keadaan ini maka akan mempengaruhi keputusan pelanggan untuk menginap di Hotel Calista Lahat.

Bentuk pengaruh dari harga dan promosi terhadap keputusan pelanggan untuk menginap dapat dibuktikan juga oleh uji analisis regresi dengan persamaan yang bertanda positif, hal ini menunjukkan bahwa pengaruh antara harga dan promosi terhadap keputusan menginap konsumen adalah pengaruh positif dengan demikian dapat dijelaskan jika pengaruh harga dan promosi terhadap keputusan menginap konsumen di Hotel Calista Lahat ditingkatkan masing-masing 1 unit skor secara bersama-sama maka akan diikuti meningkatnya keputusan menginap dan sebaliknya jika variabel harga dan promosi mengalami penurunan secara bersama-sama masing-masing 1 unit skor maka akan diikuti juga dengan menurunnya keputusan menginap konsumen Hotel Calista Lahat. Secara parsial harga dan promosi berpengaruh secara signifikan terhadap keputusan menginap konsumen di Hotel Calista Lahat.

Hasil penelitian koefisien determinasi secara parsial untuk variabel harga memberikan pengaruh terhadap keputusan konsumen untuk menginap sebesar, hasil ini menunjukan harga mempunyai pengaruh paling besar terhadap keputusan menginap konsumen, sedangkan untuk hasil deskriptif persentase terungkap bahwa responden menyatakan harga yang ditawarkan oleh Hotel Calista Lahat termasuk dalam kategori baik, karena dari semua indikator yang digunakan dalam variabel 
dalam kategori baik. Harga memberikan pengaruh yang besar karena menurut konsumen harga yang ditetapkah Hotel Calista Lahat cukup terjangkau serta cara pembayarannya yang mudah.

Promosi merupakan faktor yang mempengaruhi keputusan menginap, sehingga dapat dikatakan semakin baik promosi yang dilakukan atau semakin canggih promosi dari hotel tersebut, maka calon konsumen akan mudah untuk menentukan keputusannya, selanjutnya jika promosi yang dilakukan belum baik, maka akan terjadinya penurunan minat calon konsumen dalam menentukan keputusannya. Promosi merupakan variabel pada bauran pemasaran yang perlu dilaksanakan oleh perusahaan dalam memasarkan jasa. Promosi Hotel Calista Lahat masih tergolong cukup, seharusnya pihak hotel lebih meningkatkan lagi strategi dalam mempromosikan produk dan jasa yang dimiliki. Jika promosi dari pihak hotel sudah baik dan membuat para konsumen tertarik, maka konsumen tersebut akan langsung menentukan keputusannya, dan begitu juga sebaliknya.

\section{F. KESIMPULAN DAN SARAN \\ 1. Kesimpulan}

Berdasarkan uraian pada bab sebelumnya maka penulis mengambil kesimpulan sebagai berikut ::

a) Hasil pengolahan data manggunaka SPSS persamaan regresi yang didapat adalah : $Y=3,702+0,473 \mathrm{X} 1+0,609 \mathrm{X} 2+\mathrm{e}$

b) Pada uji t menunjukan bahwa terdapat pegaruh yang signifikan antara variabel harga dalam Meningkatkan Keputusan Pelanggan Jasa Pada Hotel Calista Lahat dan terdapat pegaruh yang signifikan antara variabel promosi dalam Meningkatkan Keputusan Pelanggan Jasa Pada Hotel Calista Lahat

c) Pada uji F menunjukkan bahwa secara bersama-sama variabel harga dan variabel promosi secara keseluruhan mempunyai pengaruh yang signifikan dalam Meningkatkan Keputusan Pelanggan Jasa Pada Hotel Calista Lahat.

d) Pada koefisien determinasi diperoleh pengaruh variabel keputusan pelanggan Jasa Pada Hotel Calista Lahat dapat dijelaskan oleh variabel harga dan variabel promosi dengan kontribusi sebesar $72,3 \%$, sedangkan sisanya sebesar 27,7 \% dapat dijelaskan oleh variabel lain yang tidak dimasukan dalam model penelitian ini.

\section{Saran}

Saran yang diajukan oleh peneliti yang dapat dijadikan acuan sesuai dengan hasil penelitian,: antara lain

a) Agar pihak hotel dapat mempertahankan dan meningkatkan dalam hal melakukan promosi seperti: memperbaharui sistem promosi dalam hal menawarkan kamar yang dimiliki, melakukan promosi lewat media sosial agar orang mudah mencari atau mendapatkan informasi yang membuat orang cepat dalam menentukan keputusannya dalam menentukan tempat untuk menginap.

b) Bagi peneliti selanjutnya untuk dapat mengembangkan kajian tentang faktorfaktor yang berkaitan dengan promosi serta faktor yang berhubungan dengan keputusan pelanggan yang belum tercantumkan dalam penelitian ini. 


\section{DAFTAR PUSTAKA}

Abdul, Thamrin dan Francis Tanti, (2016). Manajemen Pemasaran Cet. Ke - 15. Jakarta : PT. Raja Grapindo Persada.

Fontana, Avanti. (2013). Manajemen inovasi dan Penciptaan Nilai. PT. Gramedia Widiasarana Indonesia, Jakarta.

Ghozali, Imam. (2013). “Aplikasi Analisis Multivariate Dengan Program SPSS”. Edisi Ketujuh. Semarang: Badan Penerbit Universitas Diponegoro.

Nugroho J Setiadi. (2012). Perilaku Konsumen : Konsep dan Implikasi Untuk Strategi dan Penelitian Bisnis Pemasaran. Prenada Media. Jakarta

Sugiyono. (2013). Metode Penelitian kuantitatif dan R\&Q. Bandung Alfabet

Sugiyono. (2016). Metode Penelitian kuantitatif kualitatif dan $R \& Q$ Cet. Ke -22 Bandung : Alfabeta

Sumarwan, Ujang. (2013). Perilaku Konsumen. Penerbit Ghalia Indonesia, Jakarta

Suryani dan Hendriyadi. (2015). Metode Riet kuantotaif Jakarta Media Group 